\title{
Benefits of an Irrigation Scheme and Its Determinants to Surrounding Peripheral Rural Communities
}

\author{
Zandile Masela*, Abbyssinia Mushunje, Saul Ngarava, Amon Taruvinga, Simbarashe Tatsvarei \\ Department of Agricultural Economics and Extension, University of Fort Hare, South Africa \\ zandilemasela@gmail.com,AMushunje@ufh.ac.za,201501225@ufh.ac.za,ATaruvinga@ufh.ac.za, \\ tatsvarei.simbarashe@gmail.com
}

\begin{abstract}
The objective of the study was to identify the extent of benefits and their determinants to communities surrounding the Qamata Irrigation Scheme (QIS) in the Eastern Cape Province, South Africa. The study used a quantitative based cross-sectional survey of 197 households within a radius of $20 \mathrm{~km}$ from the QIS. Multiple sampling methods were utilized where the villages were randomly and the households conveniently selected. A semi-structured pre-coded questionnaire was utilized to collect the data which was analyzed using descriptive statistics and multinomial logit regression. The study identified 14 discriminant benefits ranging from job opportunities, income increment food diversification to share cropping. Sixty-two percent of the households identified less than 5 benefits, whilst $27 \%$ and $11 \%$ identified $6-10$ and $11-14$ benefits respectively. Determinants of a surrounding household to attain benefits were significantly influenced by the distance from the scheme, the main source of income and gender of household head $(\mathrm{P}<0.01)$; marital and employment status $(\mathrm{P}<0.05)$; and access to farm land $(\mathrm{P}<0.1)$. The study concludes that the level of benefit diffused to surrounding households is based on socio-economic factors. The study recommends conscientization of surrounding communities on the peripheral benefits accrued from the proximity to the QIS, achievable through awareness initiatives.
\end{abstract}

\section{Keywords: Irrigation Scheme, peripheral communities, benefit}

\section{Introduction}

Irrigation agriculture is the panacea to increase food supply, with multiplier increases in incomes, employment, and food security for the rural poor (Chazovachii, 2012; Dowgert, 2010; Dube, 2012; Hussain, 2004; Oni, Maliwichi, \& Obadire, 2011; You, et al., 2010). Irrigation enhances cultivation area and crop intensity (Sinyolo, Mudhara, \& Wale, 2014). However, there have been realizations that irrigation has produced low economic and social outputs (Arcus, 2004; Birendra, Schultz, \& Prasad, 2007; BriceñoGarmendia, Smits, \& Foster, 2008; Mutsvangwa \& Doranalli). In Sub-Saharan Africa (SSA), irrigation has been identified as a promising strategy in the endeavour to improve agricultural productivity (Xie, Wielgosz, \& Ringler, 2014). Several authors have identified two main poles of smallholder irrigation in SSA: small private irrigation and conventional irrigation schemes (de Fraiture \& Giordano, 2014; Marcella \& Eltahir, 2013; Xie, Wielgosz, \& Ringler, 2014). These have resulted from an array of factors chief among them dysfunctional institutions, poor access to markets and limited farmer skills (Pittock, Bjournlund, Stirzaker, \& Rooyen, 2017; Stirzaker, Mbakwe, \& Mziray, 2017). Figure 1 shows that land under irrigation in SSA has been gradually increasing since 1961, with little change being exhibited in Middle Africa (FAOSTAT, 2017).

Figure 1: Total Agricultural Area Devoted to Irrigation Agriculture in Eastern, Middle, Southern and Western Africa

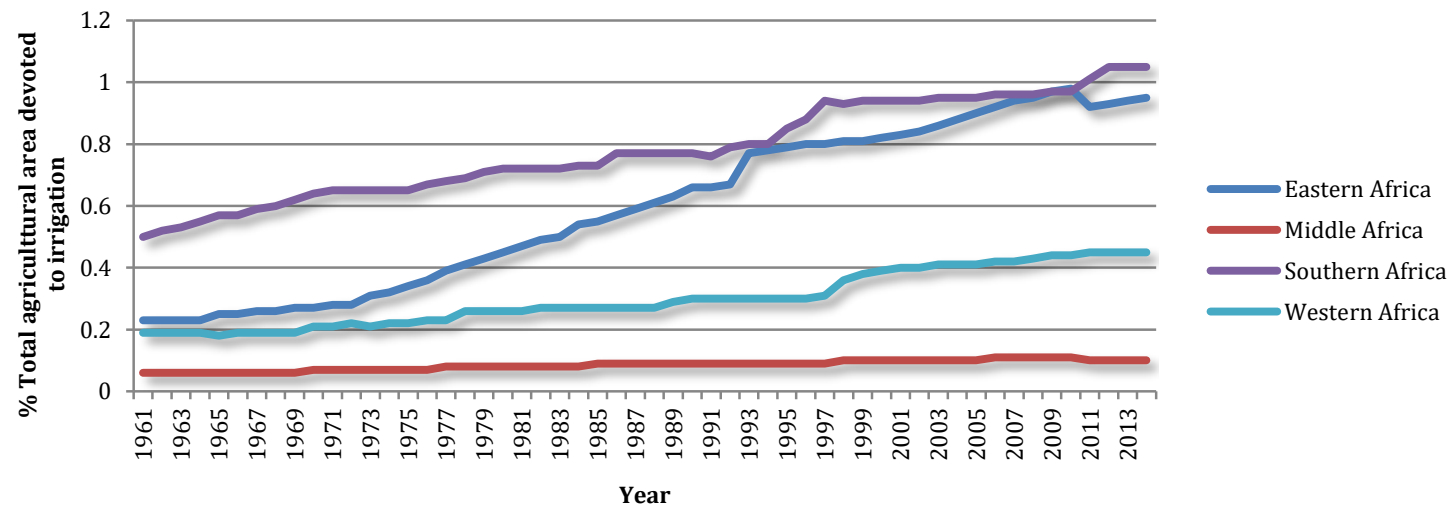

Source: (FAOSTAT, 2017) 
Southern Africa has shown the highest increase in land devoted to irrigation doubling since 1961 (FAOSTAT, 2017). This can be in direct response to being confronted by water deficit (Goldblatt, 2011). Figure 2 shows that agricultural land devoted to irrigation in Southern Africa has been dominated by South Africa, doubling from 1961 to 2014 (FAOSTAT, 2017; van Averbeke, Denison, \& Mnkeni, 2011).

\section{Figure 2: Total Agricultural Area Devoted to Irrigation Agriculture in Southern Africa}

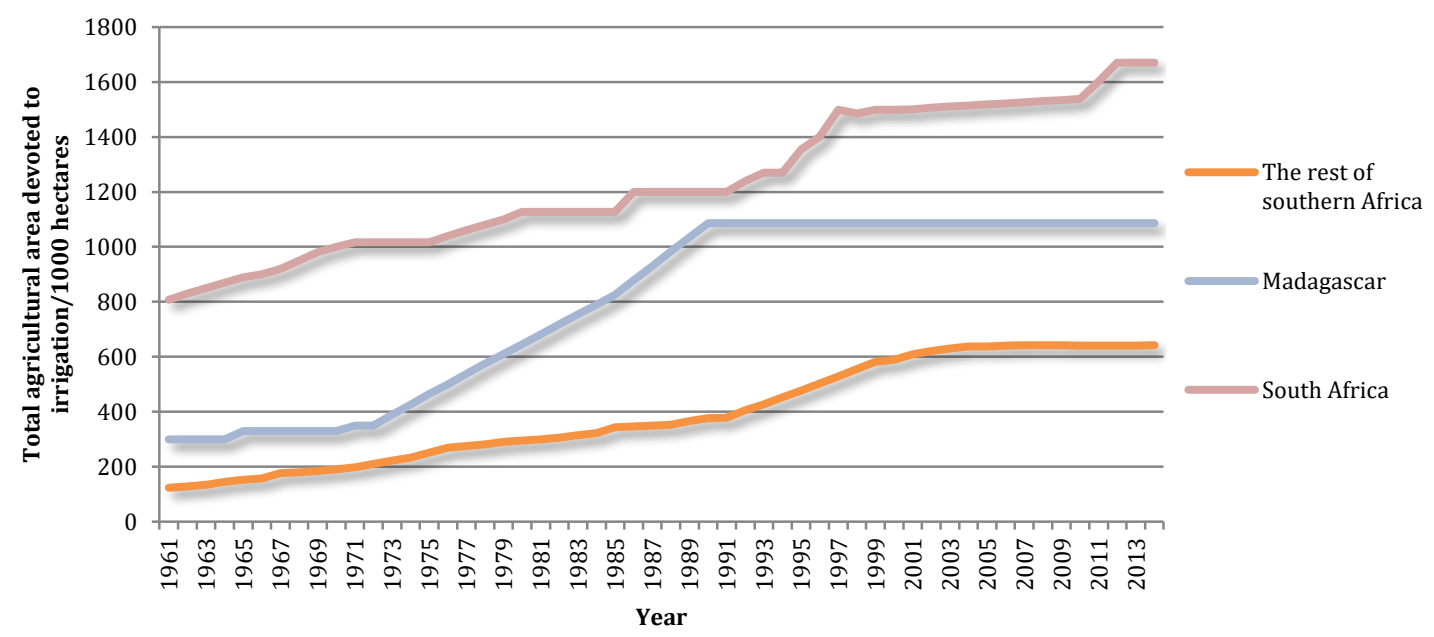

Source: (FAOSTAT, 2017)

Irrigation has been a priority in South Africa due to its water scarcity and semi-arid nature, contributing 30\% of agricultural production (Cousins, 2012; Goldblatt, 2011; Sinyolo, Mudhara, \& Wale, 2014). South Africa has 330002 households engaged in exclusive irrigation agriculture, dominated by KwaZulu-Natal (20\%), Eastern Cape (19.1\%) and Limpopo (16.6\%) Province. The Northern Cape Province has the lowest number of households engaged in irrigation agriculture at $1.98 \%$ of the total. Twenty-six percent of the agricultural households in South Africa engage in exclusive irrigated crop production, whilst $34.4 \%$ tend to combine irrigation and dry land production (StatsSA, 2016). In the year 2000, 63\% of the surface water withdrawal in South Africa was attributed to irrigation. As at 2010, the country had 302 smallholder irrigation schemes, with 206 being operational (van Averbeke, Denison, \& Mnkeni, 2011). However, in South Africa, irrigation schemes have performed poorly mainly due to poor and dilapidated infrastructure, limited farmer knowledge, lack of extension services and lack of both input and output markets (Fanadzo, Chiduza, Mnekeni, van der Stoep, \& Stevens, 2010; Gidi, 2013; Machethe, et al., 2004; van Averbeke, Denison, \& Mnkeni, 2011; Vink \& Rooyen, 2009). Despite substantial investments in irrigation schemes and rural development in South Africa, little benefits have been realized in the smallholder sector. As a result, no substantial gains in community welfare have been realized from the schemes (Gidi, 2013; van Averbeke, Denison, \& Mnkeni, 2011; Shah, van Koppen, Merrey, de Lange, \& Samad, 2002).

In South Africa, the inability of local schemes to bring about the expected social and economic development has raised doubts about irrigation being a suitable option for rural development. In South Africa, multiplier effects of benefits accruing to the entire surrounding communities were not being realized due to political, institutional and organizational challenges (Denison \& Manona, 2007). The Qamata Irrigation Scheme (QIS) was initiated in the 1960s, with the objective to alleviate natural water supply shortages leading to improved sustainable rural livelihoods through sustainable crop production for food security and poverty alleviation, sustainable job creation and micro-economic growth. The primary goal was to ease the impacts of low rainfall and support rural development (Gidi, 2013; Kodua-Agyekum, 2009; Loxton, Venn and Associates, 1998; Tracor, 1989; van Averbeke, Denison, \& Mnkeni, 2011). Farmer involvement in the planning, design, and implementation was minimal, with a centralized administration determining the use of irrigated fields and power to evict non-performers (Bembridge, 1986; FAO, 2000). Despite studies being conducted pertaining to the Qamata Irrigation Scheme (QIS), most studies have focused on the benefits accrued by the scheme participants only (Gidi, 2013; Kibirige \& Obi, 2015; Kodua-Agyekum, 2009), negating the surrounding communities. The current study, therefore, investigated the factors that determine the extent to which 
surrounding communities benefit from the QIS. Irrigation schemes involve the sharing of a distribution system for accessing irrigation water (Reinders, et al., 2010; van Averbeke, Denison, \& Mnkeni, 2011).

Smallholder irrigation schemes have failed in the reduction of farmer poverty, sustainable use of water and land as well as in maintaining irrigation infrastructure (Pittock, Bjournlund, Stirzaker, \& Rooyen, 2017). Indirect benefits accrued from irrigation through multiplier could actually outweigh the direct benefits (Husain, 2007). In India, irrigation schemes have been farmer centred negating the semi-public good characteristics providing rural economy-wide benefits (Bhattarai, Barker, \& Narayanamoorthy, 2007). Irrigation schemes play a crucial role in the surrounding communities through provision of increased productivity (Cousins, 2013; Dube, 2012), stable production (Lipton, Litchfield, \& Faurès, 2003; Ortmann \& King, 2010), job opportunities (Gundu, 2009; Sinyolo, Mudhara, \& Wale, 2014; You, et al., 2010), resulting in higher incomes (Chiwaya, 2013; Kodua-Agyekum, 2009). Irrigation schemes also enhance the local economy through forward and backward linkages with local merchants increasing labor use in the marketing and distribution sectors (Chitsa, 2014; Gundu, 2009; van Averbeke, Denison, \& Mnkeni, 2011). Proximity to other farmers in the irrigation scheme can also improve diffusion of farming husbandry information and practices among farmers themselves and surrounding communities. Ironically, the increase in production which offsets lower prices for irrigation farmers will benefit the surrounding communities through access to cheaper food. However, this will have a more profound effect on surrounding non-irrigating farmers who would also be negatively affected by these low prices (Mtonga, 2014).

A wider variety of crops can also be grown through irrigation schemes (Buthelezi, 2013). Their produce is more preferable in the local market due to its freshness, larger size, healthy looking and longer shelf life. Surrounding communities in proximity to irrigation schemes can further benefit from access to assets and entrepreneurial skills (Mombeshora, 2003; Mujuru, 2014). Despite the identified benefits from the literature, the current study argues that these benefits are context and area specific, being pertinent in some cases and irrelevant in others. Benefits accrued to irrigation vary, dependent upon the status of the beneficiary. It therefore requires that each irrigation scheme is scrutinized in its own right (Husain, 2007). Furthermore, there have been few studies that attribute socio-economic and institutional factors to benefits accrued to surrounding communities. The "sphere of influence" studies pertaining to irrigation schemes have been scanty in the South African context (van Averbeke, 2008; van Averbeke, Denison, \& Mnkeni, 2011). Identifying benefits accrued to peripheral communities is significant as input into rural development policy beyond the irrigation schemes. It identifies areas requiring attention so that irrigation schemes could provide benefits beyond the primary beneficiaries. It also improves awareness of the benefits of irrigation to nonscheme members to improve their welfare. The objective of the study was to identify the factors that determine the extent to which surrounding communities benefit from the Qamata Irrigation Scheme (QIS) in the Eastern Cape Province, South Africa.

\section{Research Methodology}

The Study Area: The study was conducted in the surrounding communities of the Qamata Irrigation Scheme (QIS) in Qamata, Intsika Yethu Local Municipality, Eastern Cape Province South Africa (Figure 3). Eastern Cape Province was purposively selected because it has the second highest number of irrigation households (6350 households) and one of the highest poverty levels in the country, with agriculture playing a significant role in poverty reduction (Tshuma \& Monde, 2012). Qamata experiences a cool climate, with temperature ranges from $14^{\circ} \mathrm{C}$ to $35^{\circ} \mathrm{C}$, with unreliable rainfall between $6 \mathrm{~mm}$ and $86 \mathrm{~mm}$ (ARDRI, 1996; Lent, Scogings, \& van Averbeke, 2000). Farmers practice dryland farming, with unreliable amount and distribution of rainfall, with high run-off and high summer temperatures reducing the effectiveness of the rainfall. Farmers in the area practice livestock farming and smallholder crop production. Dryland farming is being practiced and droughts are common and so there is a high rate of crop failure, influencing crop selection (Gidi, 2013). Qamata Irrigation Scheme (QIS), covering an area of 2601 ha, is supplied by water via gravity canal by Lubisi Dam, with the western parts of the scheme drawing water from the Great White Kei River and the Xonxa Dam (ARDRI, 1996; Kodua-Agyekum, 2009).

Research Method: The study used a cross-sectional, descriptive and quantitative-based survey interview of households in a $20 \mathrm{~km}$ radius surrounding the QIS. These households were assumed to have enough 
confluence to be influenced by the QIS. A structured pre-coded questionnaire was used as the research instrument for data collection. The data collected included socioeconomic, demographics and the benefits accrued from the proximity to the QIS. For the purpose of capturing a well-represented sample of the smallholder farmers in the study area, multiple sampling was used as the sampling technique. Qamata Irrigation Scheme (QIS) was purposively selected. This is because the scheme is one of the largest in the country.

\section{Figure 3: Map Showing Location of (a) South Africa, (b) Eastern Cape Province, (c) Intsika Yethu Local} Municipality, and (da) Qamata Irrigation Scheme

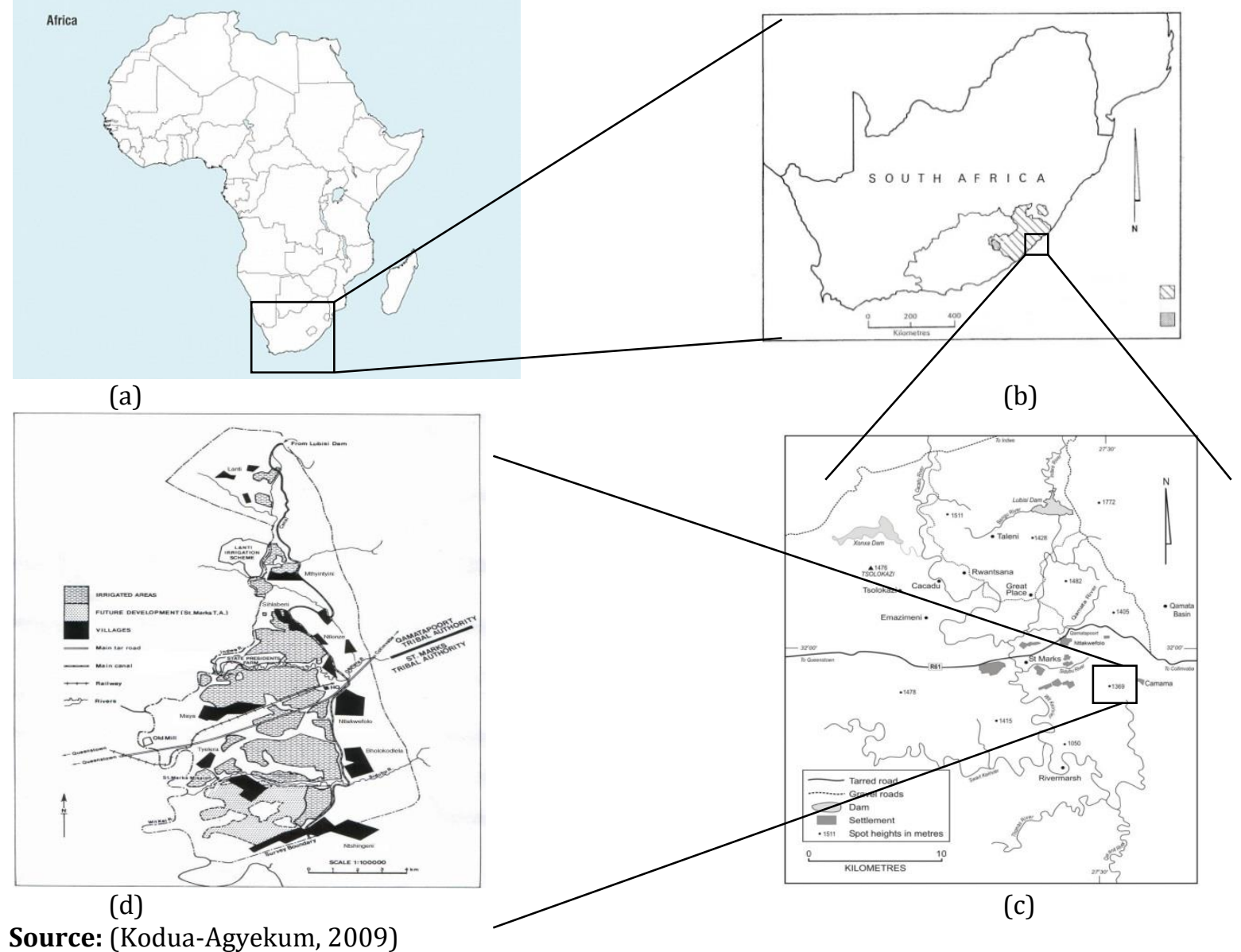

Stratified random sampling was used to select the villages, where 2 strata were selected from the 13 villages around QIS: those within a $10 \mathrm{~km}$ radius and those outside a $10 \mathrm{~km}$ radius. This was done to avoid the bias of only choosing villages that are within a $10 \mathrm{~km}$ radius, since 12 of the villages were located within the $10 \mathrm{~km}$ radius. Six villages within the $10 \mathrm{~km}$ radius were randomly selected, whilst the 1 village outside the $10 \mathrm{~km}$ radius was selected. Availability sampling was utilized in each selected village to identify a total of 197 households. This was because of the lack of a full list of all households surrounding the scheme. Furthermore, both time and financial resources restricted the sample size to 197. Descriptive statistics and multinomial logit regression were used to analyze the data, through Excel and STATA 13. Stratified random sampling was used to select the villages, where 2 strata were selected from the 13 villages around QIS: those within a $10 \mathrm{~km}$ radius and those outside a $10 \mathrm{~km}$ radius.

Analytical Framework: For the multinomial logit model, the extent (number) of benefits accrued to surrounding communities from the proximity of the QIS was classified into three distinct categories: 0-5 (low benefits); 6-10 (intermediate benefits); and 11-14 (high benefits). Rural households who benefit from the irrigation scheme are more likely to move from a low benefitting status to an intermediate benefitting status 
as well as into a high benefitting status (Bouis, 2007). Multinomial logit model predicts the probability of category membership of a dependent variable based on independent variables. The model reduces assumptions concerning homoscedasticity, linearity or normality (Schwab, 2002). The study assumed that the benefits were mutually exclusive. In the multinomial logit model, assume

$P_{r}\left\{Y_{i=j}\right\}=\frac{\exp \left[\beta_{j}^{\prime} X_{i}\right]}{\sum_{j=0}^{j} \exp \left[\beta_{j}^{\prime} X_{i}\right]}$

where $P_{r}\left\{Y_{i=j}\right\}$ is the probability of category of benefits (0-low benefits; 1 -intermediate benefits; 2-high benefits), $j$ is the number of benefiting categories in the choice set (3), $X_{i}$ is a vector of the exogenous variables, $\beta_{j}$ is a vector of the estimated parameters. When the logit equation (1) is rearranged, the regression equation is as follows:

$P_{i}=\frac{e^{\left(b_{0}+b_{1} x_{1}+\cdots+b_{v} x_{v}\right)}}{1+e^{\left(b_{0}+b_{1} x_{1}+\cdots+b_{v} x_{v}\right)}}$

Thus considering a household having a category of benefits amongst $n$ alternatives, with $X_{1 \ldots n}$ independent variables, the logit for each non-reference category $j=1, \ldots, C-1$ against the low benefit category (0) depends on the values of the independent variables, with probability parameters $\pi_{i}^{(0)}, \pi_{i}^{(1)}, \ldots, \pi_{i}^{(C-1)}$ through:

$\ln \left[\frac{\pi_{i}^{(j)}}{\pi_{i}^{(0)}}\right]=\beta_{0}^{(j)}+\beta_{1}^{(j)} X_{1 i}+\cdots+\beta_{k}^{(j)} X_{k i}$

for each $j=1, \ldots, C-1$ where $\beta_{0}^{(j)}, \ldots, \beta_{k}^{(j)}$ are unknown population parameters. This expands to:

$\ln \left[\frac{\pi_{i}^{(j)}}{\pi_{i}^{(0)}}\right]=\beta_{0}^{(j)}+\beta_{1}^{(j)} G E N+\beta_{2}^{(j)} A G E+\beta_{3}^{(j)} M A R S T+\beta_{4}^{(j)} D I S T+\beta_{5}^{(j)} S O R I N C+\beta_{6}^{(j)} E M P S T+$

$\beta_{7}^{(j)}$ ACCFRM $+\mu$

Where the independent variables include: GEN-gender of household head, $A G E$-age of household head, MARST - marital status of household head, DIST- distance from the irrigation scheme, SORINC-source of income, EMPST-employment status and ACCFRM- access to farm land as well as $\mu$,-error term.

\section{Results and Discussion}

Descriptive Results: Table 1 shows that $80.20 \%$ of the households were located within the $10 \mathrm{~km}$ radius. There were more female respondents (63.45\%) in relation to male (33.55\%), with an average age of 58.41 years, with $48.3 \%$ of the respondents having more than 60 years. Most of the respondents were married (48.22\%), with an average household size of 5. Most respondents attained education to be gainfully employed (73.60\%), living in the distance between 6 and $10 \mathrm{~km}$ from QIS. The main source of income of the households surrounding QIS is social grants, with an average annual income between R20 000 and R30 000. Most of the respondents were unemployed (85.79\%), with most having no access to land, with those having access to land having average land sizes of 1.47 hectares.

Table 1: Descriptive Results

\begin{tabular}{|c|c|c|c|c|c|c|}
\hline \multirow{3}{*}{ Variables } & \multicolumn{6}{|c|}{ Village distances from QIS } \\
\hline & \multicolumn{2}{|c|}{$<10 \mathrm{~km}$} & \multicolumn{2}{|c|}{$>10 \mathrm{~km}$} & \multicolumn{2}{|l|}{ Total } \\
\hline & Freq. & $\%$ & Freq. & $\%$ & Freq. & $\%$ \\
\hline No. of households & 158 & 80.20 & 39 & 19.80 & 197 & 100 \\
\hline \multicolumn{7}{|l|}{ Gender } \\
\hline Female & 104 & 65.82 & 21 & 53.85 & 125 & 63.45 \\
\hline Male & 54 & 34.18 & 18 & 46.15 & 72 & 36.55 \\
\hline \multicolumn{7}{|l|}{ Age } \\
\hline$<30$ & 13 & 8.23 & 2 & 5.13 & 15 & 7.61 \\
\hline $31-40$ & 20 & 12.66 & 4 & 10.26 & 24 & 12.18 \\
\hline $41-50$ & 13 & 8.23 & 6 & 15.38 & 19 & 9.64 \\
\hline $51-60$ & 33 & 20.81 & 10 & 25.64 & 43 & 21.83 \\
\hline$>60$ & 79 & 50.00 & 17 & 43.59 & 96 & 48.73 \\
\hline \multicolumn{7}{|l|}{ Educational level } \\
\hline No formal school & 37 & 23.42 & 9 & 23.08 & 46 & 23.35 \\
\hline Grade 1-12 & 115 & 72.78 & 30 & 76.92 & 145 & 73.60 \\
\hline
\end{tabular}




\begin{tabular}{|c|c|c|c|c|c|c|}
\hline Bachelors & 6 & 3.80 & & & 6 & 3.05 \\
\hline \multicolumn{7}{|l|}{ Marital status } \\
\hline Single & 49 & 31.01 & 13 & 33.33 & 62 & 31.47 \\
\hline Married & 76 & 48.10 & 19 & 48.72 & 95 & 48.22 \\
\hline Widowed & 29 & 18.35 & 4 & 10.26 & 33 & 16.75 \\
\hline Divorced & 4 & 2.53 & 3 & 7.69 & 7 & 3.55 \\
\hline \multicolumn{7}{|l|}{ Employment status } \\
\hline Unemployed & 136 & 86.08 & 33 & 84.62 & 169 & 85.79 \\
\hline Formally employed & 9 & 5.70 & 2 & 5.13 & 11 & 5.58 \\
\hline Self employed & 13 & 8.23 & 4 & 10.26 & 17 & 8.63 \\
\hline \multicolumn{7}{|l|}{ Household size } \\
\hline $1-3$ & 64 & 40.51 & 9 & 23.07 & 73 & 37.06 \\
\hline $4-6$ & 58 & 36.71 & 16 & 41.02 & 74 & 37.56 \\
\hline $7-9$ & 34 & 21.52 & 11 & 28.21 & 45 & 22.84 \\
\hline$>9$ & 2 & 1.27 & 3 & 7.69 & 5 & 2.54 \\
\hline
\end{tabular}

Figure 4 shows the benefits accrued from being close to the QIS. The figure shows that $86.3 \%$ of the respondents indicated that the QIS provided income increment, with $81.2 \%$ highlighting that the scheme provided job opportunities. A further $78.8 \%$ indicated that the scheme provides the surrounding communities with training whilst $71.4 \%$ identify it is increasing feed supply. Only $53.3 \%$ of the respondents identify the QIS improving water supply and $50.8 \%$ indicating that proximity to the scheme has lowered food prices.

\section{Figure 4: Benefits Accrued to QIS Surrounding Communities}

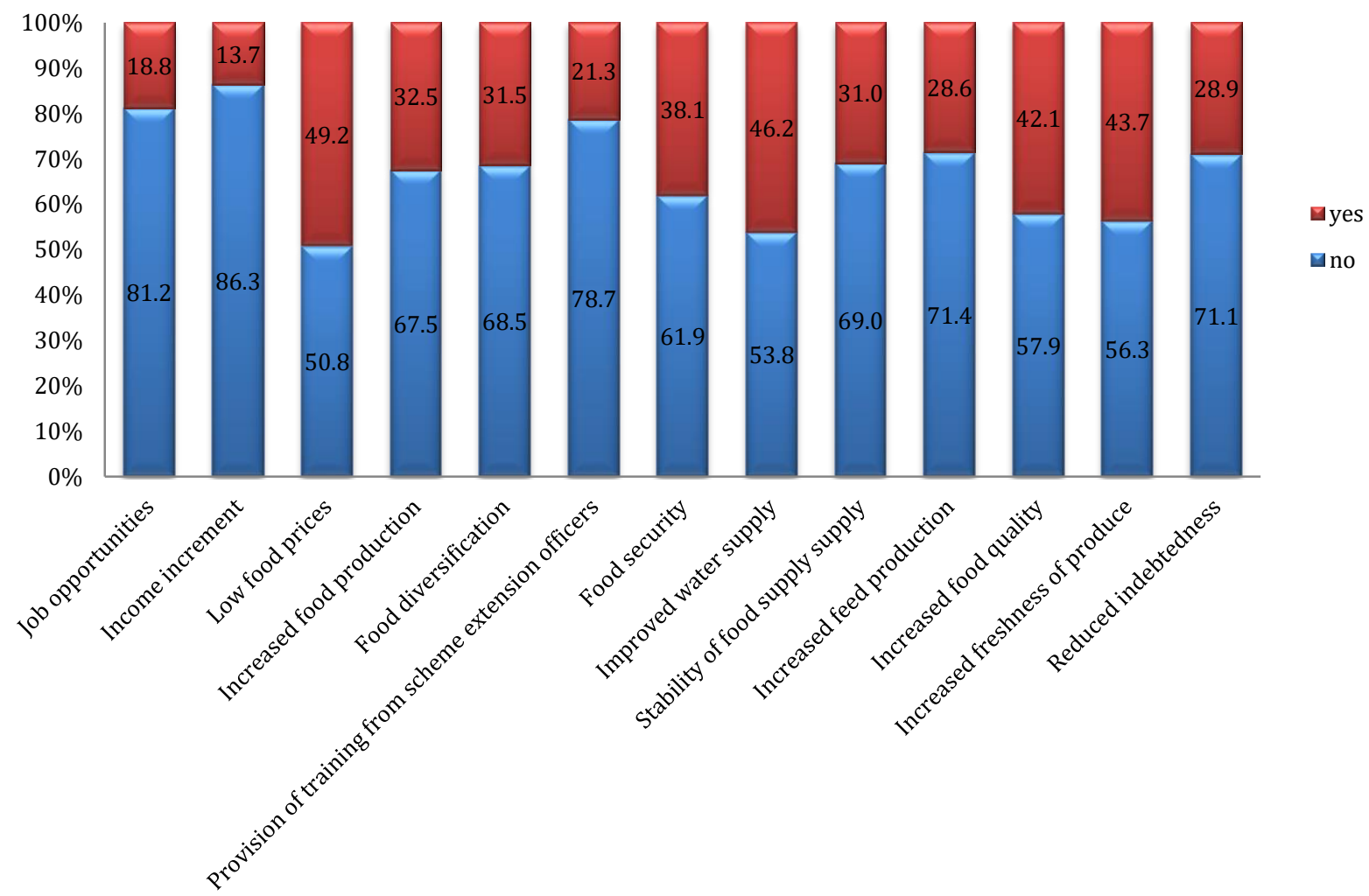

However, the perceptions of the respondents as shown in Figure 5 show that most of the respondents had a negative perception of the QIS in terms of it being an enabler in attaining benefits. 


\section{Figure 5: Perceptions of the Benefits Accrued to QIS Surrounding Communities}

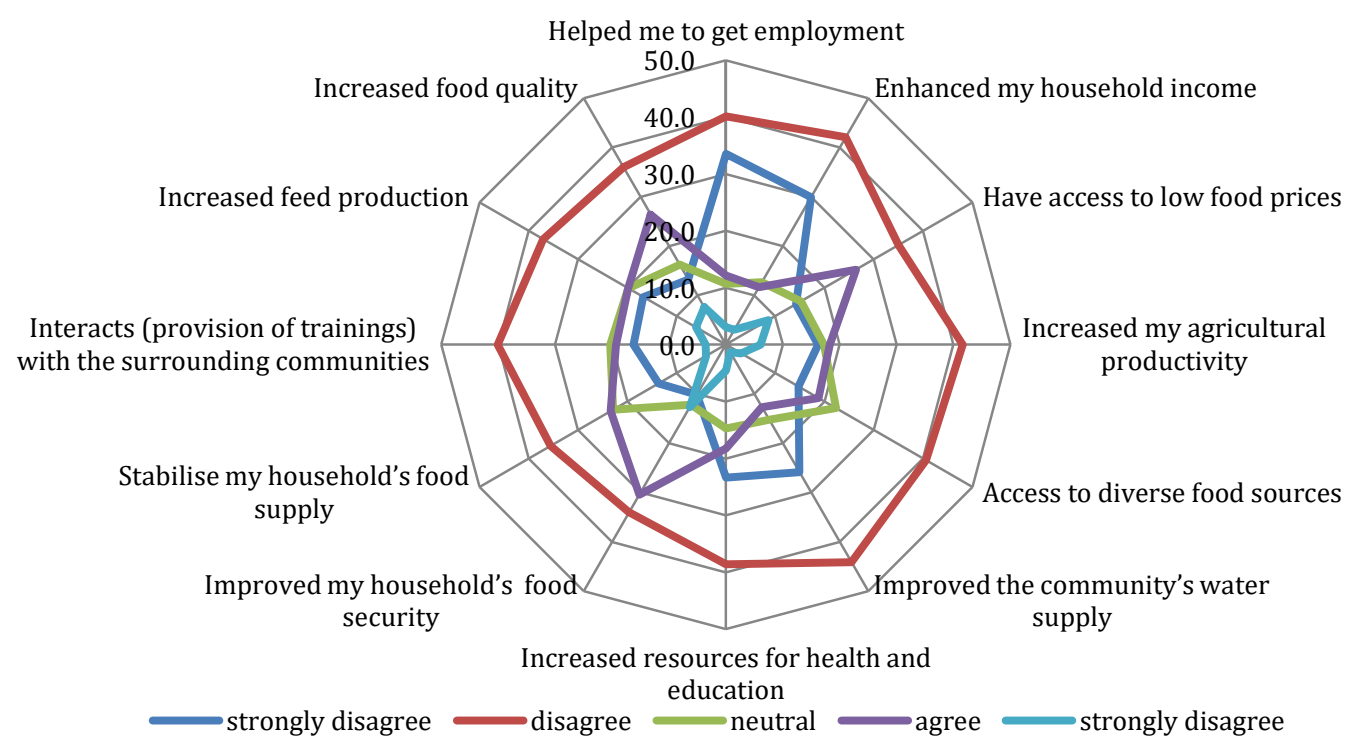

Empirical Results: Figure 6 shows that $53 \%$ of the respondents within a radius of $10 \mathrm{~km}$ from the QIS identified less than 5 benefits, whilst 33\% identified 6 to 10 benefits, with $14 \%$ having between 11 and 14 . Ninety-seven percent of the respondents in a radius exceeding $10 \mathrm{~km}$ had less than 5 benefits with $3 \%$ having between 6 and 10 benefits from the proximity of the QIS.

Figure 6: Number of Benefits Accrued to QIS Surrounding Communities

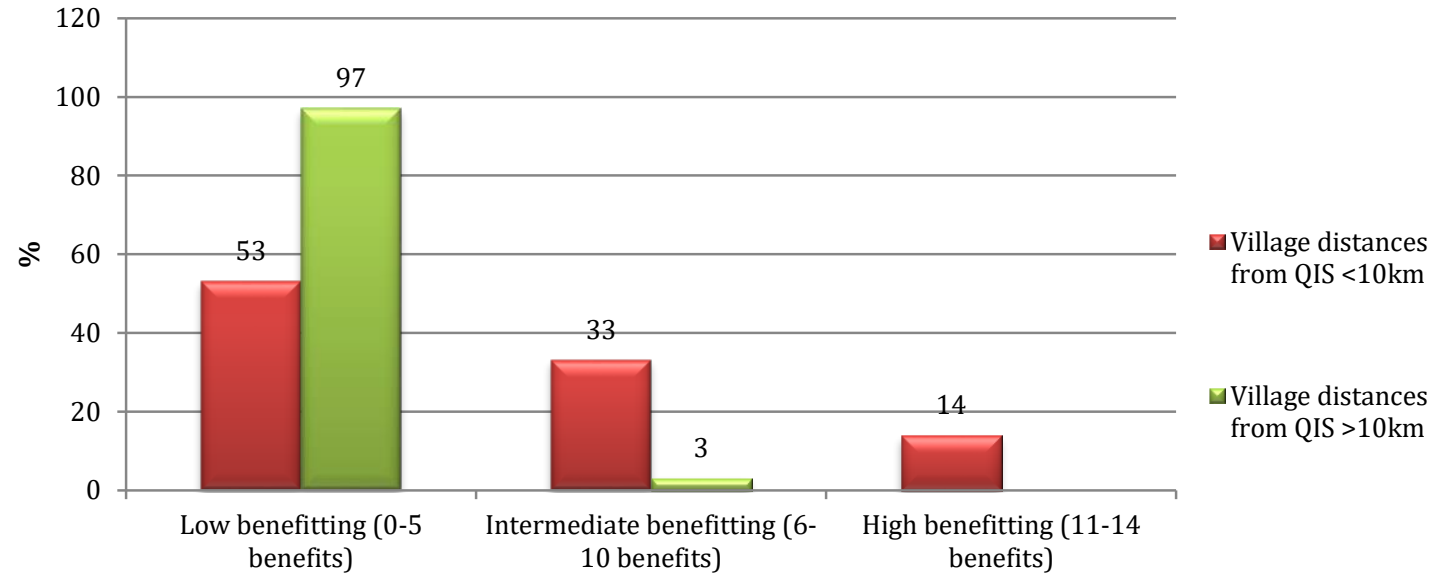

Table 2 shows that the multinomial logit model was significant at the $10 \%$ level, with gender, marital status, distance from the scheme, the main source of income, employment status and access to farmland being significant determinants of the benefits accrued to QIS surrounding communities. The $R^{2}$ value shows that the variables utilised explain $36 \%$ of the variance in the benefits accrued to proximity to the QIS. 
Table 2: Multinomial Results of Determinants of Benefits Accrued to QIS Surrounding Communities

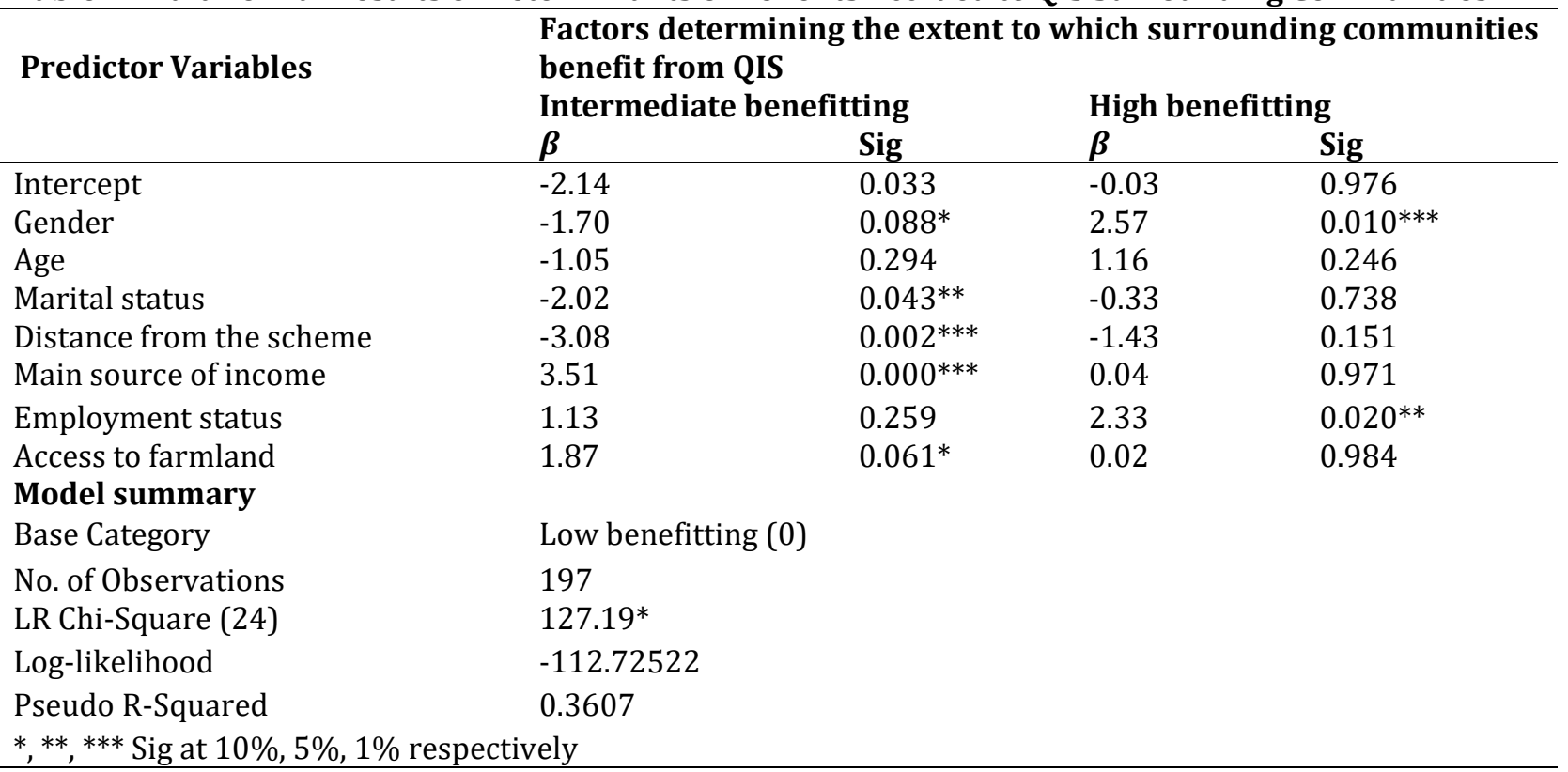

Table 2 shows that gender had a 10\% and 1\% significance of obtaining intermediate and high benefits from proximity to the QIS respectively. Intermediate benefits are likely to be realized when the household head is male whilst high benefits are more likely to be realized when the household head is female. Women provide more labor in irrigation schemes relative to males. Furthermore, female have spousal control over the food sources and its quality as well as selling agricultural output (Domenech \& Ringler, 2013). Surrounding female-headed households are therefore likely to identify more benefits from the QIS. However, the gender skewness of participating in the QIS was more slanted towards males (Kodua-Agyekum, 2009). In this case male irrigation farmers were likely to obtain more benefits in participating in the QIS whilst females who were non-QIS were going to benefit from the scheme.

Due to the patriarchal characteristics of a household in Africa, with unequal rights and access to resources, women who are peripheral to the QIS are likely to realise more benefit relative to their male counterparts (Chopra, 2004). Marital status was significant at the $5 \%$ level, with benefits likely to increase when the household head is single or married. Non-married individuals have less assets and high poverty levels, hence would accrue more benefit with proximity to an irrigation scheme (Hirschl, Altobelli, \& Rank, 2003). Single household heads have more room for mobility due to flexibility in decision making thus increasing the chances of searching for employment (Obi, 2011) and this may increase the probability of benefitting from the QIS. Distance from the QIS was significant at the $1 \%$ level, with benefits likely to increase when the distance from the scheme decreases. Other authors identified benefits being accrued to being in close proximity to irrigation schemes (Maddison, 2006). Proximity to irrigation schemes improves access to cheaper, diversified and nutritious foods; reduces cost and distance to market; and improves access to employment opportunities from the scheme (Buthelezi, 2013; Mtonga, 2014; Sinyolo, Mudhara, \& Wale, 2014; van Averbeke, Denison, \& Mnkeni, 2011). The main source of income was significant at the $1 \%$ significance level, with benefits likely to increase when more of the surrounding households receive social grants.

Being reliant on social grants means that surrounding households can engage and benefit from enhanced employment in the QIS. Other authors highlighted that most of the dry land farmers in close proximity to the QIS had social grants as a source of income (Kodua-Agyekum, 2009). This reflects that a large proportion of the household heads in proximity to the QIS were unemployed. The QIS therefore provides income opportunities through full time and part time employment within the scheme (Kodua-Agyekum, 2009). As respondents become employed, the less likely that their benefits will increase due to their proximity to the QIS. Employment status was significant at the 5\% level. Unemployed households benefit from the irrigation 
scheme because they spend enough time in the irrigation scheme to find part-time jobs (Lipton, 1996). This is supported by other authors who stated that unemployed households spend more time in irrigation schemes and that consequently increases their probability of highly benefitting from the irrigation schemes (Gidi, 2013). Equilibrium does however need to be struck between continued employment absorption and technology expansion (de Hartigh, 2016). However, this does not tally with other authors who argued that household heads which are employed may have more disposable income to have an effective demand for produce (Kodua-Agyekum, 2009).

The low prices envisaged from the proximity to the QIS also offers a benefit to surrounding households with low annual incomes from social grants. However, households with a regular source of income are more likely to benefit from irrigation schemes than those who do not have a regular source of income (Thangata, Hindebradt, \& Gladwin, 2002). The low prices can be attributed to the communities' surrounding irrigation schemes face due to the small surrounding farm gate market, which lacks organized markets and guaranteed producer prices (Kodua-Agyekum, 2009). Access to farmland was significant at the $1 \%$ level indicating that the more a respondent surrounding the QIS had access to land the more likely benefits will accrue to that individual. This could be because households with access to farmlands produce a variety of crops thus benefit from improved community water supply and provision of training. Other authors partitioned direct benefits of irrigation directed to landholders whilst indirect benefits being realised by smallholders and the landless (Husain, 2007). Comparable conclusions were also suggested by (Bouis, 2007) who argued that in households with access to farmlands, there is high agricultural productivity with improvements in nutrition and welfare.

\section{Conclusion and Recommendations}

In conclusion, because of their proximity to the QIS, households are benefitting from income increments, job opportunities, training, increased feed supply, reduced indebtedness and a stabilized food supply. Furthermore, they are also benefiting in terms of diversified food supply, increased food production, food security and improved food quality. In addition, the surrounding households benefit through fresh food supply, improved water supply, and low food prices. The study identified that factors such as gender of the household head and their marital status, distance from the scheme, the main source of income, employment status of household head and access to farmland were major determinants of the benefits accrued to QIS surrounding communities. Women obtain more benefits from being in close proximity to irrigation schemes. This is exacerbated by their side-lining in participating in irrigation schemes due to patriarchy. Unmarried individuals in close proximity also benefit from employment opportunities created by irrigation schemes. The further the distance from irrigation schemes, the less benefits that accrue due to proximity to the scheme.

Unemployed individuals who have access to social welfare gained more benefit in having proximity to the irrigation scheme, mainly through accessing part-time and seasonal jobs. The proximity to the irrigation scheme reduced agricultural output prices which were beneficial to the surrounding communities by improving access to more food with higher quality, but however not beneficial to surrounding farmers who will face low producer prices. Benefits of proximity to the irrigation scheme were also more pronounced to a household with access to land, since the training and water use could also diffuse to non-scheme farmers. The study recommends conscientization of surrounding communities on the peripheral benefits accrued from the proximity to the QIS. This should take into cognizance the gender sensitivity of the benefits accrued to surrounding communities as well as their socio-economic circumstances to realize the full benefits of being in close proximity to an irrigation scheme.

\section{References}

Arcus, G. (2004). Principle, approach and guidelines for the participatory revitalization of smallholder irrigation schemes. East London, South Africa: Arcus Gibb.

ARDRI. (1996). Qamata irrigation scheme. The University of Fort Hare, Faculty of Agriculture and ARDRI, Alice, South Africa.

Bembridge, T. J. (1986). Problems and lessons from irrigation projects in less developed countries of Africa. Development Southern Africa, 2(2), 600-618. 
Bhattarai, M., Barker, R. \& Narayanamoorthy, A. (2007). Who benefits from irrigation development in India? Implication of irrigation multipliers for irrigation financing. Irrigation and Drainage, 56(2-3), $207-$ 225.

Birendra, K. C., Schultz, B. \& Prasad, K. (2007). Water management to meet present and future food demand. Irrigation and Drainage, 60(3), 348-359.

Bouis, H. E. (2007). The potential of genetically modified food crops to improve human nutrition in developing countries. Journal of Development Studies, 43, 79-96.

Briceño-Garmendia, C., Smits, K. \& Foster, V. (2008). Fiscal costs of infrastructure in Sub-Saharan Africa. World Bank. Washington DC: Africa Infrastructure Country Diagnostic.

Buthelezi, T. C. (2013). Pro-poor value chain governance in the Mtateni Irrigation Scheme. Unpublished MC Thesis, University of Western Cape, Faculty of Economic and Management, Cape Town, South Africa.

Chazovachii, B. (2012). The impact of small-scale irrigation schemes on rural livelihoods: The case of Panganai irrigation scheme, Bikita District, Zimbabwe. Journal of Sustainable Development in Africa, $14(4), 217-231$.

Chitsa, G. (2014). Analysis of entrepreneurial behaviour of smallholder irrigation farmers: Empirical evidence from Qamata Irrigation Scheme. Unpublished MSc Thesis, Univerity of Fort Hare, Department of Agricultural Economics and Extension, Alice, South Africa.

Chiwaya, W. G. (2013). Contribution of small-scale irrigation schemes to the livelihood of rural households. Unpublished MSc Thesis, Mzumbe University.

Chopra, M. (2004). Food security, rural development and health equity in Southern Africa. Discussion Paper Number 22, University of Western Cape, Regional Network for Equity in Health in Southern Africa (EQUINET).

Cousins, B. (2012). Smallholder irrigation schemes, agrarian reform and accumulation from below: Evidence from Tugela Ferry, KwaZulu-Natal. Paper presented at the Conference on Strategies to Overcome Poverty and Inequality: Towards Carnegie III. Cape Town, South Africa, 3-7 September: University of Cape Town.

Cousins, B. (2013). Smallholder irrigation schemes, agrarian reform and accumulation from above and from below in South Africa. Journal of Agrarian Change, 13(1), 116-139.

de Fraiture, C. \& Giordano, M. (2014). Small private irrigation: A thriving but overlooked sector. Agriculture Water Management, 131, 167-174.

de Hartigh, W. (2016, May 11). Agriculture is still creating employment in South Africa.

Denison, J. \& Manona, S. (2007). Principles, approaches and guidelines for the participatory revitalization of smallholder irrigation schemes: Volume 1-A rough guide for irrigation development practitioners. Water Research Commission. Pretoria, South Africa: WRC.

Domenech, L. \& Ringler, C. (2013). The impact of irrigation on nutrition health and gender: A review paper with insights for Africa south of the Sahara. IIFPRI Discussion Paper 01259, International Food Policy Research Institute, Environment and Production Technology Division.

Dowgert, M. F. (2010). The impact of irrigated agriculture on a stable food supply.

Dube, K. (2012). The socio-economic impact assessment of Lower Gweru Irrigation Scheme in Gweru, Zimbabwe. University of South Africa, Department of Geography. University of South Africa.

Fanadzo, M., Chiduza, C. \& Mneki, P. N. (2010). Overview of smallholder irrigation schemes in South Africa: Relationship between farmer crop management practices and performance. African Journal of Agriculture Research, 5(25), 3514-3523.

Fanadzo, M., Chiduza, C., Mnekeni, P. S., van der Stoep, I. \& Stevens, J. (2010). Crop production management practices as a cause for low water productivity at Zanyokwe Irrigation Scheme. Water South Africa, 36(1), 27-36.

FAO. (2000). South Africa: Affordable irrigation technologies for smallholders: Opportunities for technology adaptation and capacity building. Programme formulation. Food and Agriculture Organization, Environment and Production Technology Division. Rome, Italy: IPTRID Secretariat.

FAOSTAT. (2017). Agricultural area devoted to irrigation agriculture in Southern Africa. FAO. Food and Agriculture Organization.

FAOSTAT. (2017). Agricultural area devoted to irrigation in Eastern, Middle, Southern and Western Africa. Food and Agriculture Organization. FAO. 
Gidi, L. S. (2013). Rural households' livelihood strategies and opportunities with regard to farming: A case of Intsika Yethu Local Municipality. University of Fort Hare, Department of Agricultural Economics and Extension. Alice, South Africa.

Goldblatt, A. (2011). Agriculture: Facts and trends: South Africa. (T. Bormann, Ed.) World Wide Fund.

Gundu, M. (2009). The effect of literacy on access to and utilisation of agricultural information for household food security and Chirau communal lands in Zimbabwe. Unpublished MSc Thesis, University of Fort Hare, Department of Library and Information Science, Alice, South Africa.

Hirschl, T. A., Altobelli, J. \& Rank, M. (2003). Does marriage increase the odds of affluence? Exploring the life course possibilities. Journal of Marriage and the Family, 65, 627-938.

Husain, I. (2007). Direct and indirect benefits and potential disbenefits of irrigation: Evidence and lessons. Irrigation and drainage, 56(2-3), 179-194.

Hussain, L. (2004). Agriculture water and poverty linkages. Case studies on large and small systems. In A. D. Bank (Ed.), Water and poverty: The realities, experiences from the field (pp. 55-73). Manilla: Asian Development Bank.

Kibirige, D. \& Obi, A. (2015). Agricultural efficiency of smallholder farmers in Eastern Cape Province, South Africa. International Journal of Economics, Commerce and Management, 3(9), 296-289.

Kodua-Agyekum, C. (2009). The transfer of technology to the rural poor: The case of Qamata irrigation scheme in the Eastern Cape Province of South Africa. University of KwaZulu-Natal, Department of Policy and Development Studies. Pietermaritzburg, South Africa.

Lent, P., Scogings, P. F. \& van Averbeke, W. (Eds.). (2000). Natural resource and policy in Eastern Cape Province, South Africa: Overview Paper (Vol. Working Paper 4). Alice, South Africa, South Africa: Agricultural and Rural Development Research Institute.

Lipton, M. (1996). Rural reforms and rural livelihoods: The context of international experience. In M. Lipton, M. de Klerk, \& M. Lipton (Eds.), Land, labour and livelihoods in rural South Africa. Dalbridge, Durban, South Africa: Indicator Press.

Lipton, M., Litchfield, J. \& Faurès, J. M. (2003). The effects of irrigation on poverty: A framework for analysis. Water Policy, 5-6, 413-427.

Loxton, Venn and Associates. (1998). The Qamata Irrigation Scheme, Project Development Plan. Loxton, Veen and Associates for Qamata Farmers Cooperative.

Machethe, C. L., Mollel, N. M., Ayisi, K., Mashatola, M. B., Anim, F. D. \& Vanasche, F. (2004). Smallholder irrigation and agricultural development in the Olifants basin of Limpopo Province: Management, transfer, productivity, profitability and food security issues. Water Research Council. Pretoria, South Africa: WRC.

Maddison, D. (2006). The perception of and adaptation to climate change in Africa. CEEPA Discussion Paper No. 10, University of Pretoria, Centre for Environmental Economics and Policy in Africa, Pretoria, South Africa.

Marcella, M. P. \& Eltahir, E. A. (2013). Introducing an irrigation scheme to a regional climate model: A case study over West Africa. Journal of Climate Change, 27, 5708-5723.

Mombeshora, S. (2003). Water and livelihoods: The case of Tsovani Irrigation Scheme in Sangwe, Southeastern Zimbabwe. Sustainable Livelihoods in Southern Africa: Institutions,

Mtonga, M. (2014). The impact of small-scale irrigation projects on food security: The case of Inkosikazi Irrigation Project instituted by World Vision in Wards 4 and 5 in the Bubi District, Zimbabwe. MA, University of South Africa, Department of Development Studies.

Mujuru, J. T. (2014). Entrepreneurial agriculture and human development: A case study of Dotito Irrigation Scheme, Mt Darwin. International Journal of Humanities and Social Science, 4(4), 121-131.

Mutsvangwa, T. \& Doranalli, K. (n.d.). Agriculture and sustainable development. 2006, Netherlands: The Hague University Press.

Obi, A. (Ed.). (2011). Institutional constraints to small farmer development in Southern Africa. Netherlands: Wageningen Academic Publisher,

Oni, S. A., Maliwichi, L. L. \& Obadire, O. S. (2011). Assessing the contribution of smallholder irrigation to household food security, in comparison to dryland farming in Vhembe district of Limpopo Province, South Africa. African Journal of Agricultural Research, 6(10), 2188-2197.

Ortmann, G. F. \& King, R. P. (2010). Research on agri-food supply chains in Southern Africa involving smallscale farmers: Current status and future possibilities. Agrekon, 49(4), 397-417. 
Pittock, J., Bjournlund, H., Stirzaker, R. \& Rooyen, V. (2017). Communal irrigation systems in South-Eastern Africa: Findings on productivity and profitability. International Journal of Water Resources Development, 33(5), 839-847.

Reinders, F. B., van der Stoep, I., Lecler, M. L., Greaves, K. R., Vahrmeijer, J. T., Benade, N. \& Ascough, G. (2010). Standards and guidelines for improved efficiency of irrigation water use from dam wall release to root zone application: Guidelines. Water Research Commission. Pretoria, South Africa: WRC.

Schwab, J. A. (2002). Multinomial logistic regression: Basic relationship and complete problems.

Shah, T., van Koppen, B., Merrey, D., de Lange, M. \& Samad, M. (2002). Institutional alternatives in African smallholder irrigation: Lessons from international experience with Irrigation Management Transfer. IWMI Research Report 60, International Irrigation Management Institute, Colombo, Sri Lanka.

Sinyolo, S., Mudhara, M. \& Wale, E. (2014). The impact of smallholder irrigation on household welfare: The case of Tugela Ferry irrigation scheme in KwaZulu-Natal, South Africa. Water South Africa, 40(1), 146-147.

StatsSA. (2016). Agricultural households: Community Survey. Pretoria, South Africa.

Stirzaker, R., Mbakwe, I. \& Mziray, N. (2017). A soil water and solute learning system for small-scale irrigators in Africa. International Journal of Water Resource Development, 33(5), 788-803.

Thangata, P. H., Hindebradt, P. E. \& Gladwin, C. H. (2002). Modelling agroforestry adoption and household decision making in Malawi.

Tracor. (1989). Lati Irrigation Scheme: Operating and capital budget1989-1990. Department of Agriculture and Forestry, Umtata, Eastern Cape Province.

Tshuma, M. \& Monde, N. (2012). A socio-economic impact assessment of a project to identify and implement best management practices at Zanyokwe irrigation scheme at farm level. Water South Africa, 38(5), 783-792.

van Averbeke, W. (2008). Best management practices for sustainable farming on selected irrigation schemes and surrounding areas through participatory adaptive research in Limpopo Province. Water Research Commission. Pretoria, South Africa: WRC.

van Averbeke, W., Denison, J. \& Mnkeni, P. N. (2011). Smallholder irrigation schemes in South Africa: A review of knowledge generated by the Water Research Commission. WRC 40-Year Celebration Special Edition, 37(5), 797-808.

Vink, N. \& Rooyen, J. (2009). The economic performance of agriculture in South Africa since 1994: Implications for food security. Development Bank of Southern Africa, Development Planning Division. Halfway House.

Xie, H., Wielgosz, B. \& Ringler, C. (2014). Estimating the potential for expanding smallholder irrigation in Sub Saharan Africa. Agricultural Water Management, 131, 183-193.

You, L., Ringler, C., Nelson, G., Wood-Sichra, U., Robertson, R., Wood, S. \& Sun, Y. (2010). What is the irrigation potential for Africa? A combined biophysical and socio-economic approach. IFPRI, Discussion Paper 00993. Washington D. C, 